\title{
КОНСТИТУЦИОННО-КОНФОРМНОЕ ТОЛКОВАНИЕ ЗАКОНОВ И ВЕРХОВЕНСТВО КОНСТИТУЦИИ
}

\begin{abstract}
Аннотация: В статье раскрываются особенности конституционно-конформного толкования конституциии исходя из систематики права, цуелосности и гармоничности правовой системы. Конформное толкование рассматривается как метод обеспечение правовой определенности, один из средств преодолениня пробелов и коллизий в законодательстве. В качестве юридической основы конституционно-конформного толкования лежит идея обеспечения дейстивя конституционных норм як реально действующего и эффективного порядка, а также поливариантность применения конституционных положений в условиях правовой неопределенности. Эти факторы становлятся ключевыми при применении закона и иных правовых актов только в тех аспектах, в которых они удовлетворяют требования конституционности. На основе сравнительно-правового анализа дана характеристика особенностей структуры конституциионно-конформного толкования, которая определяется предметом правового регулирования, респределением правотворческих полномочий, административной и судебной практикой. Сформулированы основные подходы преодоления законодательньх пробелов и коллизий, которые не отвечают требованиям правовой определенности и они должны быть преодолены с помощью применения тех норм текущего законодательства, которое соответствует конституционным ценностям, принципам и нормам. Abstract: The article is devoted to the specific features of constitutional conforming interpretation of the Constitution, based on systemic quality of law, harmonious and united character of the legal system. Conforming interpretation is a method for guaranteeing legal certainty, and it is one of the methods for overcoming gaps and conflicts in legislation. The basis of constitutional conforming interpretation is the idea of guarantees of implementation of constitutional norms as a directly applicable and efficient order, as well as polyvariety of application of constitutional provisions in the situation of lack of legal certainty. These factors are key to application of law and other normative acts only in those cases, when they meet constitutionality requirements. Based on comparative legal analysis, the author provides characteristic features of structure of constitutional conforming interpretation, which is defined by the object of legal regulation, administrative and judicial practice. The author formulates key approaches to overcoming legislative gaps and conflicts, which fail to meet the requirements of legal certainty, and they should be overcame by application of the norms of current legislation, which conform to constitutional values, norms, and principles.
\end{abstract}

Ключевые слова: верховенство конституцฺи, верховенство права, коллизия, конституциионая юриспруденция, конституциионная юстиция, конституцчионно-конформное толкование, конституционность, правовое регулирование, пробел в законодательстве, толкование конституцчии

Keywords: supremacy of the Constitution, supremacy of law, conflict of laws, constitutional jurisprudence, constitutional justice, constitutional conforming interpretation, constitutionality, legal regulation, gap in the legislation, interpretation of the Constitution.

\section{І. Введение.}

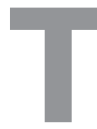
олкование норм конституционным судами не должно приводить к своеобразной «инфляции» конституционно -правовой материи , вносить дополнительные коллизии в правовую систему. Иначе коллизии между правовыми нормами могут нарушать единство и преемственность правовой системы, несущей угрозу верховенству и стабильности конституции, принципам функционирования правовой государственности. Ведь любой акт конституционных судов должен толковаться с целью обеспечения его внутреней согласованности с правовой системой в целом, поскольку системный способ толкования имплицитно предполагает отсутствие противоречий внутри акта, подлежащего толкованию. Учитывая это, конституционные суды оказываются перед дилеммой: признавать неконституционным правовой акт или его норму в случае, если он вносит дополнительные коллизии в содержание норм действующей Конституции Украины или угрожает единому пониманию ее положений или толковать такую коллизию или пробел в конституционном контексте? И будет ли признание этого правового акта оправданным с точки зрения правовой определенности (четкости, предсказуемости последствий 
DOI: 10.7256/1811-9018.2013.13.9690

При цитировании этой статьи сноска на dоі обязательна

\section{Право и политика $13(168) \cdot 2013$}

юридической силы правовых норм) и правомерности ожиданий (стабильности законодательства)?

В этой статье будет идти речь об обоснованности конституционно-конформного толкования законов и иных правовых актов контексте обеспечения правовой определенности, обоснованных (правомерных) ожиданий как элементов верховенства конституции и обеспечения целостности и гармоничности национальной правовой системы. В первой части статьи пойдет речь об обосновании конституционно-конформного толкования законов, во второй - об элементах такого метода толкования.

\section{II. Основы конституционно-конформного толкования законов и иных правовых актов.}

Необходимость обеспечения единства правовой системы при толковании конституции не может сводить деятельность конституционных судов к роли своеобразного «негативного законодателя», поскольку и конституционные суды творят право. При таких условиях уместно говорить о принципах конституционно-конформного толкования законов, поскольку затронутые вопросы достаточно сложно решить в рамках традиционного или динамического толкования. Конституционноконформное толкование законов (verfassungkonforme Interpretation/Auslegung, consistent interpretation, la sentence interpretative, reserves d'interpretation) заключается в избрании компромиссного варианта интерпретации конституционных норм, по которым даже в случае выявления неконституционности положений правового акта, являющегося предметом конституционного контроля, он признается действующим в части, в которой он отвечает конституционным принципам и нормам ${ }^{1}$. Такая практика широко распространена в странах Европы и Северной Америки. Это случается, когда интерпретированные положения правового акта вызывают неоднозначное толкование и исходя из конкретной юридической ситуации ему предоставляется толкование исключительно в контексте конституционных принципов и норм. В дальнейшем орган конституционной юстиции не принимает во внимание положения правового акта, которые являются сомнительными с точки зрения его конституционности.

\footnotetext{
${ }^{1}$ Deutsches Staatsrecht. Ein Studienbuch von Reinhold Zippelius und Thomas Würtenberger. 31. Auflage des von Theodor Maunz begründeten Werkes. München : Verlag C.H. Beck München, 2005. s. 59; Decision of Constitutional Conceil of French Republic 92-308 DC of 2 September $1992 / /$ http://www.conseil-constitutionnel.fr/conseilconstitutionnel/root/bank_mm/anglais/a92308dc.pdf
}

Конституционный суд Чешской республики в своем решении Pl. US 48/95 от 26.03.1996 года признал правомерным «принцип приоритета конституционного конформного толкования перед признанием недействительным закона». На основе этого Суд отметил, что «в ситуации, когда конкретное положение правового акта (pravniho predpisu) делает возможным два различных толкования, причем одно из них соответствует конституционному закону и международным договорам в соответствии со статьей 10 Конституции Чешской республики, а другое - противоречит, не предоставляется вывод о недействительности этого положения. При его решении задачей суда является толкование этого положения в конституционно конформный способ»².

Конституционно-конформное толкование законов является дискуссионным с точки зрения легитимности судебного активизма ${ }^{3}$, поскольку выражает правотворческую функцию конституционной юстиции в случаях правовой неопределенности. Согласно принципам конституционности в деятельности органов конституционной юстиции конформное толкование должно основываться на принципах разделения властей и не может содержать потенциальное вмешательство в сферу дискреции законодателя.

Конформность (от лат. Conformis - подобный, похожий) - термин, которым характеризуют приспособления к существующему порядку вещей, принятие существующих тенденций, господствующих взглядов и доктрин. Термин «конформность» редко употребляется в украинском конституционном праве, поскольку он на сегодня не адаптирован в толковых словарях, которые, например, интерпретируют его вроде «соблюдения конформизма» или «приспособленчество»,

\footnotetext{
${ }^{2}$ Nales Pl. US 48/95 26.03.1996 roku o interpretace zakona v souladu s ustavnymi zakony a mezinarodnymi smlouvami dle ul. 10 Ustavy // http://nalus.usoud.cz/Search/ResultDetail.aspx?id=27983\&pos=4\&c $\mathrm{nt}=12$ \&typ $=$ result

${ }^{3}$ Вей C. Принципи конституційної інтерпретації і самообмеження конституційного судді // Вісник Конституційного Суду України. 2002. № 2. С. 57-59; Кляйн Ханс Х. Юрисдикция конституционного суда и структура конституции. От правового государства к конституционному государству // Государство и право. 1999. № 8. C. 111-112; Савчин М. Природа актів Конституційного Суду України: теоретико-методологічні аспекти // Вісник Конституційного Суду України. 2007. №5. С.71-78; Тодыка Ю.Н. Толкование Конституции и законов Украины: теория и практика: Монография. Х. : Факт, 2001. 328 с.; Шевчук С. Основи конституційної юриспруденції. К. : Український центр правничих студій, 2001. 294 с.; Шевчук С. Судова правотворчість. Світовий досвід і перспективи в Україні. К. : Реферат, 2006. 640 с.
} 
«соглашательство» ${ }^{4}$. Только словарь иностранных слов трактует его как «сходство», «соответствие»5. Таким образом, адаптация к конституционному пониманию конформного толкования правовых актов состоит в его интерпретации только в соответствии с конституционным содержанием правовой нормы.

\section{III. Основные элементы конституционно-конформного толкования.}

Для выявления содержания правовой нормы при конституционно-конформном толковании применяются такие элементы, как выявление значения слов и их грамматическое конструирование, анализ содержательных связей норм закона с одновременным сопоставлением с целью регулирования в историческом контексте и объективно целевых элементов. Вместе с тем при интерпретации важными являются критерии обеспечения единства конституции, соответствие практике и функционально-правовой адекватности, которое охватывается системным толкованием ${ }^{6}$. Таким образом, конституционные суды в процессе интерпретации конституции должны взвешенно подходить к оценке конституционности той или иной нормы, а принятый в результате этого акт конституционной юриспруденции должен быть результатом взвешенного толкования и последовательного анализа.

В соответствии с принципами конституционноконформного толкования, закон нельзя признавать недействительным (неконституционным), если его можно толковать как отвечающим конституции. Конституционно-конформное толкование - довольно распространенное явление в немецкой конституционной юриспруденции? ${ }^{7}$ Конституционный суд, разрешая конституционный конфликт, должен строить свою интерпретационные деятельность, в том числе на основе конформного толкования оспариваемых норм, основываясь на таких принципах толкования

\footnotetext{
${ }^{4}$ Великий тлумачний словник сучасної української мови / Уклад. і голов. ред. В.Т. Бусел.К.; Ірпінь : ВТФ «Перун», 2002. С. 452.

${ }^{5}$ Словник іншомовних слів: 23000 слів та термінологічних словосполучень / Уклад. В.О. Пустовіт та ін. К. : Довіра, 2000. С. 556.

${ }^{6}$ Государственное право Германии. Сокращ. перевод с нем. в 2-х т. / Под ред. В.А. Туманова. Т. 2. М. : ИГП РАН, 1994. С. 315-316, 317.

${ }^{7}$ Геберле П. Загальні проблеми конституційного права та юрисдикції конституційного суду на матеріалі «німецької моделі» і 3 погляду на Україну // Вісник Конституційного Суду України. 2001. №6. С.59-72; Рижков Г. Принцип правової держави в Основному Законі (Конституції) ФРН і судова практика Федерального Конституційного Суду ФРН. К. : Книги для бізнесу, 2008. 112 с.
}

конституционных норм, как: единство (целостность) конституции, принцип практического согласования (конкордации) и правовой определенности.

Например, Конституционный Суд Российской Федерации, рассматривая вопросы конституционности отдельных льгот по тарифам по перевозке пассажиров воздушным транспортом, также давал их анализ, применяя конституционно-конформный способ интерпретации Конституции Российской Федерации. В частности, Суд ссылается на требования правовой определенности, необходимым условием которого является сохранение баланса между частными и публичными интересами - расходы «на перевозку детей в возрасте от двух до двенадцати лет по льготному тарифу авиакомпаниям-перевозчикам, осуществляющим общественно значимую функцию, создает неопределенность в вопросе как о самом наличии, так и о способе возмещения таких расходов». Далее Суд подчеркнул: «Эта неопределенность в правовом регулировании не может быть устранена и конституционно-правовым истолкованием положения подпункта 3 пункта 2 статьи 106 Воздушного кодекса Российской Федерации, которое - исходя из его содержания и, соответственно, предназначения - не позволяет выявить волю федерального законодателя относительно решения вопроса о расходах на перевозку детей по льготному тарифу, включая определение размера этих расходов».

Поскольку этот вопрос связан со свободой усмотрения (дискрецией) федерального законодателя, а также то, что вопрос тарифов несет характер технических норм и соответствующей правоприменительной практики, Конституционному Суду сложно было дать оценку правомерности правил по формированию тарифов и льгот по них на авиационном транспорте, исходя только из конституционных положений. Поэтому Конституционный Суд Российской Федерации далее подчеркнул, что законодатель обязан «при осуществлении возложенных на него полномочий принимать во внимание необходимость обеспечения баланса конституционно значимых интересов, включая недопустимость нарушения прав и свобод других лиц при осуществлении прав и свобод человека и гражданина (статья 17, часть 3, Конституции Российской Федерации), с одной стороны, и стабильности правоотношений в интересах их участников - с другой, в настоящем деле считает возможным воздержаться от признания положения подпункта 3 пункта 2 статьи 106 Воздушного кодекса Российской Федерации не соответствующим Конституции Российской Федерации в той мере, в какой в системе действующего правового регулирования им не предусматривается механизм 
DOI: $10.7256 / 1811-9018.2013 .13 .9690$

При цитировании этой статьи сноска на доі обязательна

\section{Право и политика $13(168) \cdot 2013$}

возмещения авиакомпании-перевозчику расходов на перевозку детей в возрасте от двух до двенадцати лет в соответствии с льготным тарифом с предоставлением им отдельных мест». О применении конституционноконформного способа интерпретации законов и иных правовых актов недвусмысленно подтверждает пункт второй резолютивной части Постановления № 29-П, в котором Суд признает возможным воздержаться «от признания положения подпункта 3 пункта 2 статьи 106 Воздушного кодекса Российской Федерации не соответствующим Конституции Российской Федерации в той мере, в какой в системе действующего правового регулирования, включая положения иных нормативных правовых актов, регламентирующих вопросы тарифной политики в области перевозок пассажиров воздушным транспортом, им не предусматривается механизм возмещения авиакомпании-перевозчику расходов на перевозку детей в возрасте от двух до двенадцати лет в соответствии с льготным тарифом с предоставлением им отдельных мест» ${ }^{8}$. В свою очередь, Суд обязал федерального законодателя внести в действующее правовое регулирование необходимые изменения, направленные на соблюдение конституционного баланса публичных и частных интересов в сфере перевозок воздушным транспортом детей в возрасте от двух до двенадцати лет в соответствии с льготным тарифом с предоставлением им отдельных мест.

Эта практика Конституционного Суда Российской Федерации, как справедливо отмечает российский конституционалист Г. Гаджиев, отображает положения федерального законодательства и конституционной доктрины, в силу которых «предметом исследования в конституционном судопроизводстве должен быть не первоначальный смысл нормы, а реальная правовая норма, полученная в результате преобразования «первоначальной» нормы посредством: а) официального ее истолкования; б) иного истолкования; в) либо в результате сложившейся правоприменительной практики». Такая практика признается автором плодотворной, поскольку ее «социологический» характер дает возможность преобразовывать ее смысл, исходя из правовой реальности 9 .

Таким образом, конституционные суды при интерпретации прежде всего призваны обеспечить един-

\footnotetext{
${ }^{8}$ Постановление Конституционного Суда Российской Федерации № 29-П от 20 декабря 2011 года по делу о компенсации затрат авиакомпании // http://www.rg.ru/2012/01/11/ks-avia-dok.html.

9 Гаджиев Г.А. Конституционный принцип самостоятельности судебной власти в Российской Федерации // Журнал российского права. № 2003. № 1 .
}

ство понимания правовых норм, ее целью является однозначное и правильное понимание и применение положений конституции, международных договоров, законов и подзаконных нормативно-правовых актов. Согласно конституционно-конформному толкованию законов решается не только вопрос о конституционности содержания закона, но и анализируется содержание конституции, с которой закон должен быть согласован. То есть в данном случае интерпретируются в диалектической взаимосвязи как сама конституция, так и конституционные аспекты закона, обеспечивающего их тесную взаимосвязь, а также единство правопорядка ${ }^{10}$. Следствием применения этого метода являются: если возможна интерпретация закона согласно конституции, то он подлежит признанию действующим в этой части, он служит основным средством конкретизации конституции. Однако применение конституционно-конформного толкования законов в данном случае может оставить так невыясненными проблемы разграничения функций конституционной и общесудовой юрисдикции.

\section{IV. Украинский опыт конституционно-конформной интерпретации.}

Применение конституционно-конформного толкования Конституционным Судом Украины довольно противоречиво. Например, Конституционный Суд Украины в решении № 4-рп/2010 ${ }^{11}$, осуществив анализ оспариваемого пункта Положения об общеобразовательном учебном заведении в системном толковании с нормами Конституции Украины, пришел к выводу, что в нем воспроизводится содержание частей первой, третьей статьи 10 , части пятой статьи 53 Конституции Украины. В этой части оспариваемое положение не может считаться неконституционным. Однако другая оспариваемая норма, которой Кабинет Министров, дополняя пункт 46 Положения абзацем вторым, вышел за пределы своих полномочий, предусмотренных Конституцией и законами Украины, обязав педагогов постоянно применять украинский язык, не только в учебном процессе, но и фактические в частной сфере, была признана Судом противоречащей Конституции Украины.

\footnotetext{
${ }^{10}$ Тихий В. Офіційне тлумачення Конституції та законів України Конституційним Судом України // Вісник Конституційного Суду України. 1998. № 4. С. 38 - 45.

${ }^{11}$ Решение Конституционного Суда Украины № 4-рп/2020 от 4 февраля 2010 года // http://ccu.gov.ua/uk/doccatalog/list?currDir=94600 (на укр. языке)
} 
Неудачным примером конформно-конституционного толкования является решение Конституционного Суда Украины № 11-рп/2010 12, которым было признано конституционным участие внефракционных депутатов в формировании коалиции депутатских фракций как легитимной основы инвеституры правительства, хотя это достоверно не вытекало из анализа действующей на то время части третьей статьи 83 Конституции. Квинтэссенция этого решения основывалась на конституционных гарантиях свободы политической деятельности (статья 15), определении принципов свободного мандата парламентария (хотя он также имел на то время элементы так называемой «партийной» императивности) и свободе усмотрения Верховной Рады определять в Законе о своем регламенте порядок формирования коалиции фракций. Следует согласиться, что ошибочность этого решения заключается в том, что Суд фактически уравнял по юридической силе Конституцию и Закон о Регламенте Верховной Рады (особое мнение судьи П. Стецюка), исказив сущность содержания юридической конструкции положения части третьей статьи 83 Конституции (особое мнение судьи В . Шишкина). Из анализа этого решения видно, что Конституционный суд Украины не выяснил все конституционные аспекты содержания мандата парламентария, чтобы предоставлять толкование противоречивым аспектам его регулирования на уровне Регламента Верховной Рады, нарушив принципы иерархии правовых актов, определенных частью второй статьи 8 Конституции Украины. В конце концов, нельзя давать интерпретации конституционным положениям через положения законов, если в этой части Конституция определяет фундаментальные принципы и ограничивает свободу усмотрения парламента, как таковая ограничивалась в части третьей статьи 83 Конституции Украины (в редакции Закона № 2222-IV от 8 декабря 2004 г.).

С учетом зарубежного и украинского опыта конституционной юрисдикции можно выделить следующие формы конституционно-конформного толкования законов: а) толкование конституции во взаимосвязи с международными договорами; б) толкование конституции в контексте учредительных актов Европейского Союза и правовых актов органов ЕС; в) толкование конституции в контексте Конвенции о защите прав человека и основных свобод 1950 г. и прецедентного права Европейского суда по правам человека; г) тол-

\footnotetext{
${ }^{12}$ Решение Конституционного Суда Украины № 11-рп/2010 от 6 апреля 2010 года // http://ccu.gov.ua/uk/doccatalog/list?currDir=106790 (на укр. языке).
}

кование конституции во взаимосвязи с положениями нормативно-правовых актов, являющихся предметом конституционного контроля.

\section{V. Выводы. \\ Конституционно-конформное толкование и проблема пробелов и коллизий в законодательстве.}

Сегодня существует необходимость развития конституционных положений в текущем законодательстве, поскольку это ведет к состоянию законодательного упущения (дефекта законов) и возможности исполнительной власти злоупотреблять своими полномочиями в условиях правовой неопределенности. В данном случае усилия конституционной юрисдикции по интерпретации конституции далеко не всегда дают возможность обеспечить реальную защиту прав человека и основоположных свобод. В этом смысле конституционные положения накладывают позитивные обязанности на законодателя по поводу надлежащего правового регулирования. Возникает вопрос самоконтроля законодателя, что, по мнению Г. Госепата, может быть достигнуто через конституционный суд, который призван осуществлять контроль текущего законодательства на предмет эффективного обеспечения основных прав ${ }^{13}$.

Таким образом, Конституция дополняется и развивается текущим законодательством и конституционной юриспруденцией. В частности, положения конституции как нормативного акта конкретизируются и детализируются в правовых актах конституционного суда. Парламент при принятии законов связан конституционной юриспруденцией (совокупностью правовых позиций конституционных судов по тем же конституционным положениям и одному и тому же предмету правового регулирования) относительно конституционных положений, на развитие которых принимается соответствующий закон. Это вытекает из принципа res judicata актов конституционной юриспруденции, которые не нуждаются в дополнительном подтверждении со стороны других органов публичной власти ${ }^{14}$ и издания дополнительных правовых актов, что может служить дополнительным источником инфляции законов и внесение неопределенности в механизм правового регулирования.

\footnotetext{
${ }^{13}$ Філософія прав людини / За ред. Ш. Госепата та Г. Ломанна. К. : Ніка-Центр, 2008. С. 188-189.

${ }^{14}$ Стрижак А.А., Рибалко Я.В., Савчин М.В. Закон України «Про Конституційний Суд України»: наук.-практ. комент.; за заг. ред. А.А. Стрижака. К.: Ін Юре, 2009. С. 226-228.
} 
DOI: $10.7256 / 1811-9018.2013 .13 .9690$

При цитировании этой статьи сноска на dоі обязательна

\section{Право и политика $13(168) \cdot 2013$}

Разрешение конституционных споров конституционными судами следует рассматривать средством обеспечения динамического развития норм права в соответствии с существующими социально-политическими условиями и достижениями конституционной традиции. Следует согласиться с мнением, что для этого конституционные суды могут использовать различные методы: а) исправить пробелы в действующем законодательстве путем толкования состояния правового регулирования с последующим преодолением пробелов в действующем законодательстве; б) признать неконституционным обнаруженные пробелы в действующем законодательстве и обязать субъект правотворчества устранить такое упущение; в) хотя и не признавать законодательные пробелы неконституционными, однако критически их оценив, рекомендовать субъекту правотворчества исправить их и предоставить для судов обязывающее толкование, указав о преюдиции своего решения ${ }^{15}$. Такая деятельность органов конституционной юстиции относительно толкования конституции является имманентной и позволяет преодолевать пробелы в действующем законодательстве, обеспечивая верховенство конституции и единство национальной правовой системы.

\section{Библиография:}

1. Бирмонтене Т., Ярашюнас Э., Спруогис Э. Генеральный доклад XIV Конгресса Конференции европейских конституционных судов // Конституционное правосудие: Вестник Конференции органов конституционного контроля стран молодой демократии. Выпуск 2 (40) - 3 (41), 2008. Ереван : Центр конституционного права Республики Армения, 2008. С. 70 - 245.

2. Вей С. Принципи конституційної інтерпретації і самообмеження конституційного судді // Вісник Конституційного Суду України. 2002. № 2. С. 57-59.

3. Великий тлумачний словник сучасної української мови / Уклад. і голов. ред. В.Т. Бусел.К.; Ірпінь : ВТФ «Перун», 2002. 1440 c.

\footnotetext{
${ }^{15}$ Бирмонтене Т., Ярашюнас Э., Спруогис Э. Генеральный доклад XIV Конгресса Конференции европейских конституционных судов // Конституционное правосудие: Вестник Конференции органов конституционного контроля стран молодой демократии. Выпуск 2 (40) - 3 (41), 2008. Ереван : Центр конституционного права Республики Армения, 2008. С. 70 - 245.
}

4. Гаджиев Г.А. Конституционный принцип самостоятельности судебной власти в Российской Федерации // Журнал российского права. № 2003. № 1.

5. Геберле П. Загальні проблеми конституційного права та юрисдикції конституційного суду на матеріалі «німецької моделі» і з погляду на Україну // Вісник Конституційного Суду України. 2001. №6. C.59-72.

6. Государственное право Германии. Сокращ. перевод с нем. в 2-х т. / Под ред. В.А. Туманова. Т. 2. М. : ИГП РАН, 1994. 320 c.

7. Кляйн Ханс Х. Юрисдикция конституционного суда и структура конституции. От правового государства к конституционному государству // Государство и право. 1999. № 8 С. 111-112.

8. Постановление Конституционного Суда Российской Федерации № 29-П от 20 декабря 2011 года по делу о компенсации затрат авиакомпании // http:// www.rg.ru/2012/01/11/ks-avia-dok.html.

9. Решение Конституционного Суда Украины № 4-рп/2020 от 4 февраля 2010 года // http:// ccu.gov.ua/uk/doccatalog/list?currDir $=94600$ (на укр. языке)

10. Решение Конституционного Суда Украины № 11рп/2010 от 6 апреля 2010 года // http://ccu.gov.ua/ uk/doccatalog/list?currDir=106790 (на укр. языке).

11. Рижков Г. Принцип правової держави в Основному Законі (Конституції) ФРН і судова практика Федерального Конституційного Суду ФРН. К. : Книги для бізнесу, 2008. 112 с.

12. Савчин М. Природа актів Конституційного Суду України: теоретико-методологічні аспекти // Вісник Конституційного Суду України. 2007. №5. C.71-78.

13. Словник іншомовних слів: 23000 слів та термінологічних словосполучень / Уклад. В.О. Пустовіт та ін. К. : Довіра, 2000. 1018 с.

14. Стрижак А.А., Рибалко Я.В., Савчин М.В.Закон України «Про Конституційний Суд України»: наук.-практ. комент.; за заг. ред. А.А. Стрижака. К.: Ін Юре, 2009. 328 c.

15. Тихий В. Офіційне тлумачення Конституції та законів України Конституційним Судом України // Вісник Конституційного Суду України. 1998. № 4. C. $38-45$.

16. Тодыка Ю.Н. Толкование Конституции и законов Украины: теория и практика: Монография. Х. : Факт, 2001. 328 с.

17. Шевчук С. Основи конституційної юриспруденції. К. : Український центр правничих студій, 2001. 294 с. 
18. Шевчук С. Судова правотворчість. Світовий досвід і перспективи в Україні. К. : Реферат, 2006. 640 с.

19. Філософія прав людини / За ред. Ш. Госепата та Г. Ломанна. К. : Ніка-Центр, 2008. 317 с.

20. Decision of Constitutional Conceil of French Republic 92-308 DC of 2 September 1992 // http://www.conseil-constitutionnel.fr/conseil-constitutionnel/root/ bank_mm/anglais/a92308dc.pdf

21. Deutsches Staatsrecht. Ein Studienbuch von Reinhold Zippelius und Thomas Würtenberger. Auflage des von Theodor Maunz begründeten Werkes. München : Verlag C.H. Beck München, 2005. $561 \mathrm{~s}$.

22. Nales Pl. US 48/95 26.03.1996 roku o interpretace zakona v souladu s ustavnymi zakony a mezinarodnymi smlouvami dle ul. 10 Ustavy // http://nalus.usoud.cz/ Search/ResultDetail.aspx $? \mathrm{id}=27983 \&$ pos $=4 \& \mathrm{cnt}=12$ \&typ $=$ result

\section{References (transliteration):}

1. Birmontene T., Yarashyunas E., Spruogis E. General'nyi doklad XIV Kongressa Konferentsii evropeiskikh konstitutsionnykh sudov // Konstitutsionnoe pravosudie: Vestnik Konferentsii organov konstitutsionnogo kontrolya stran molodoi demokratii. Vypusk 2 (40) - 3 (41), 2008. Erevan : Tsentr konstitutsionnogo prava Respubliki Armeniya, 2008. S. 70 - 245.

2. Vei S. Printsipi konstitutsiinoï interpretatsiï i samoobmezhennya konstitutsiinogo suddi // Visnik Konstitutsiinogo Sudu Ukraïni. 2002. № 2. S. 57-59.

3. Gadzhiev G.A. Konstitutsionnyi printsip samostoyatel'nosti sudebnoi vlasti v Rossiiskoi Federatsii // Zhurnal rossiiskogo prava. № 2003. № 1.

4. Geberle P. Zagal'ni problemi konstitutsiinogo prava ta yurisdiktsiï konstitutsiinogo sudu na materiali «nimets'koï modeli» i z poglyadu na Ukraïnu //
Visnik Konstitutsiinogo Sudu Ukraïni. 2001. №6. S.59-72.

5. Klyain Khans Kh. Yurisdiktsiya konstitutsionnogo suda i struktura konstitutsii. Ot pravovogo gosudarstva k konstitutsionnomu gosudarstvu // Gosudarstvo i pravo. 1999. № 8. S. 111-112.

6. Rizhkov G. Printsip pravovoï derzhavi v Osnovnomu Zakoni (Konstitutsiï) FRN i sudova praktika Federal'nogo Konstitutsiinogo Sudu FRN. K. : Knigi dlya biznesu, 2008. $112 \mathrm{~s}$.

7. Savchin M. Priroda aktiv Konstitutsiinogo Sudu Ukraïni: teoretiko-metodologichni aspekti // Visnik Konstitutsiinogo Sudu Ukraïni. 2007. №5. S.71-78.

8. Strizhak A.A., Ribalko Ya.V., Savchin M.V.Zakon Ukraïni «Pro Konstitutsiinii Sud Ukraïni»: nauk.prakt. koment.; za zag. red. A.A. Strizhaka. K.: In Yure, 2009. $328 \mathrm{~s}$.

9. Tikhii V. Ofitsiine tlumachennya Konstitutsiï ta zakoniv Ukraïni Konstitutsiinim Sudom Ukraïni // Visnik Konstitutsiinogo Sudu Ukraïni. 1998. № 4. S. $38-45$.

10. Todyka Yu.N. Tolkovanie Konstitutsii i zakonov Ukrainy: teoriya i praktika: Monografiya. Kh. : Fakt, 2001. $328 \mathrm{~s}$.

11. Shevchuk S. Osnovi konstitutsiinoï yurisprudentsiï. K. : Ukraïns'kii tsentr pravnichikh studii, 2001. $294 \mathrm{~s}$.

12. Shevchuk S. Sudova pravotvorchist'. Svitovii dosvid i perspektivi v Ukraïni. K. : Referat, 2006. $640 \mathrm{~s}$.

13. Deutsches Staatsrecht. Ein Studienbuch von Reinhold Zippelius und Thomas Würtenberger. Auflage des von Theodor Maunz begründeten Werkes. München : Verlag C.H. Beck München, 2005. $561 \mathrm{~s}$.

14. Nales Pl. US 48/95 26.03.1996 roku o interpretace zakona $\mathrm{v}$ souladu s ustavnymi zakony a mezinarodnymi smlouvami dle ul. 10 Ustavy // http://nalus.usoud.cz/ Search $/$ ResultDetail.aspx $? \mathrm{id}=27983 \&$ pos $=4 \& \mathrm{cnt}=12$ \&typ $=$ result 